\title{
The Promise and Limits of Leveraging Black Athlete Power Potential to Compel Campus Change
}

\author{
Harry Edwards, $\mathrm{PhD}$ \\ University of California, Berkley
}

In the wake of developments at the University of Missouri in 2015, where Black athletes joined with Black student groups on campus and threatened a boycott of football until Black student demands for campus culture and leadership changes were agreed to, I have been asked on many occasions if I am saddened or discouraged by the need for campus battles today demanding changes that I fought for nearly 50 years ago. Quite the contrary. We should be neither surprised nor dismayed over the facts that battles thought won continue to be waged or that there are new battles being fought to sustain gains thought secured. Put most simply, THERE ARE NO FINAL VICTORIES! Only "THE STRUGGLE" and "THE PEOPLE" on whose behalf it is waged endure. All else is delusion and illusion, and in time inevitably will fade and pass away like the morning mist before the rising sun of a new day. Such are the lessons of biography and history informing my perspective, a perspective born of 50 years of experience on the "front lines" of struggle around issues at the interface of sport, race, and society - and with this reality, I am not only at peace, I am pleased. What follows is an autoethnographic account of the cyclical nature of human history and how new technologies can become weapons that precipitate current sociopolitical movements.

During the week of September 22, 1967 - over 48 years ago - I organized a movement in protest of institutionally entrenched anti-Black racism and discrimination in the policies, operations, and campus culture of San Jose State University (SJSU). As a former SJSU scholarship athlete, I made "leveraging the power potential" (Edwards, 2016) of the Black athletes on campus (who dominated the revenue-producing sports of football and basketball as well as track and field) the central feature of the movement's change strategy. This tack was all the more legitimate because, at the time, the athletic department shared in and manifested many of the school's anti-Black discriminatory dispositions (the one exception being its willingness to exploit Black athlete sports talent and to recruit Black athletes to that purpose in inordinately high numbers relative to Black representation in any other sector of campus life). Secondly, I organized and demanded university recognition of a Black student advocacy group, United Black Students for Action (UBSA). And most significantly, I threatened to organize a Black athlete boycott of the season-opening home football game against the University of Texas at El Paso if a list of demands were not met. Chief among those demands were:

The desegregation of all on-campus housing units and off-campus "University-approved" housing; 
The total desegregation of all university-recognized fraternities and sororities - a significant portion of University-approved on-campus housing - and the removal of all race-specific exclusionary and discriminatory clauses from fraternity and sorority charters;

The establishment of programs of outreach, recruitment and financial support targeting nonathlete Black student high school populations;

The establishment of programs to recruit and retain tenure track Black faculty in every department of the University, and to increase the numbers of Black administrators at SJSU;

The inclusion of Black coaching and administrative prospects in the job interview and hiring pools of the athletic department, particularly insofar as revenue-producing sports are concerned;

Academic support programs and services for enrolled Black students and Black athletes, with the goal of enhancing overall Black student academic performance and increasing Black graduation rates;

A "Black Studies Program" with the goals of creating and developing courses and other curricula offerings in every department of the University that would explore, present, and analyze the Black experience and contributions within each disciplinary context and encourage the hiring of Black faculty in each department who, along with regular teaching duties, would help structure and establish more diverse courses; and

The hiring of a high level administrative officer specifically responsible for monitoring, reporting, and resolving issues of racism and discrimination on campus.

As the movement progressed, Black football players from both SJSU and the U. of Texas, El Paso began to express a reluctance to play the game in the face of the protest effort and mounting outside threats of violence and disruption of the game if it were to be played. In response, the President of SJSU, Dr. Robert Clark, decided to immediately institute policy changes in faculty hiring practices that promised a significant increase in the numbers of Black and other minority candidates in the facility candidate pool; to order the desegregation of all oncampus and approved off-campus housing - including fraternities and sororities; to establish an "Educational Opportunity Program" (EOP), an outreach and financial support program targeting minority, low income, and "at-risk" high school students; to create and staff a Black Studies Program (later re-named the Department of African-American Studies); to include Blacks in the candidate pools for coaching and administrative jobs in the Athletic Department; and to establish the administrative position of "Campus Ombudsman" to monitor, report, and resolve issues of racism, discrimination, and exclusion on the campus. President Clark also promised establishment of a faculty-student review board to consider "best practices" methods and mechanisms potentially conducive to helping alter the overall racial climate and culture at the university -- a promise that never came to fruition.

Nonetheless, due to increasing vitriolic discourse, tension, and hostility between campus 
and community interests relative to the movement and the school's efforts to meet its demands, President Clark eventually felt compelled to cancel the SJSU - University of Texas, El Paso football game altogether in the interest of public safety. Consequently, under increasing pressure and criticism from all sides, within two years, Dr. Clark resigned as President of SJSU.

Over the ensuing years, the attention of journalists and schools has been focused principally upon three prospects: (1) the cancellation of the football game; (2) upon the facts that this was the first time in National Collegiate Athletic Association (NCAA) Division I history that an athletic event had been cancelled in the wake of racial turmoil and unrest, and the first time in the post-Jackie Robinson era of widely desegregated locker rooms in mainstream sports that Black athletes at a predominantly White collegiate institution had been party to a threatened boycott of an athletic event; and (3) upon the political wisdom of an institution conceding the fact of institutional racism and committing to meeting protest demands for corrective actions under threat of a Black athletes' boycott of a scheduled sports event

But there are other, more seminal and salient aspects and dimensions of the 1967 SJSU movement that warrant exploration and analysis. Understanding these aspects not only brings greater clarity to what happened at SJSU in 1967, it also informs and helps establish a better grasp and comprehension of the contemporary politics and dynamics occurring at the interface of education, race, sport and society in protest situations such as that at the University of Missouri.

First, the SJSU movement did not occur in a sociopolitical vacuum. Though the movement was precipitated by long standing racist and discriminatory policies and practices at SJSU, it was also to some substantial degree fueled and framed by developments in both the broader society and the larger sports institution. In terms of immediate precipitating factors, Black students at SJSU were mostly viewed as an "alien" element within the campus population and culture, a racial and numerical "oddity" (72 Black students - mostly current or former athletes - out of a student body population of 22,000). They were marginalized, ignored, alienated and socioculturally invisible in the broader campus culture because the SJSU community and power structure were oblivious to Black student issues, interests, and realities. Only in the sports realm, in the activity space of football games, basketball games, and track and field meets was there any formal institutional and SJSU popular community recognition of Black students' existence and contribution to campus life. With only two Black faculty members including myself, then a part-time lecturer in the Department of Sociology - and no Black administrative personnel at all, Black exclusion and estrangement from mainstream campus life, culture, input and influence within the SJSU community was so thoroughly institutionalized that it was accepted as "normal" by the university. Initially, when, on separate occasions, I had approached two administration officials with my concerns, in both instances my enunciation of issues was dismissively greeted as a "practical joke". They both literally laughed at the very idea of ending discrimination in university-approved student housing, hiring Black coaches and more Black faculty, and recruiting more non-athlete Black students, etc. At one point, one of the officials suggested that "the problem" was that I was even raising these issues! (Edwards, 1969). Beyond the contradictions of Black circumstances on the SJSU campus, there were also 
influences emanating from the broader society that impacted the political and ideological framing of SJSU movement, its demands and tactics. There was, first, a burgeoning Black cultural and political movement that, in part, reflected a growing militancy among Black youth. Its slogan was "Black Power!", and it manifested a substantial break with traditional Black civil rights leadership and leadership organizations. Led and projected by younger leaders such as Stokely Carmichael and H. "Rap" Brown of the Student Non-Violent Coordinating Committee, and Huey Newton and Bobby Seale of the Black Panther Party, the "Black Power! Movement" was also strongly influenced by the pronouncements and philosophies of the late Malcolm X (particularly as articulated in his autobiography, Haley, 1992). "Black Power!" demands constituted a shift from the civil rights establishment's goal of undifferentiated accommodation and assimilation within the White mainstream. The focus of "Black Power!" was gaining control of the nascent power potential of Black society and leveraging that power in the interests of Black people irrespective of whether that leveraging was applied within a White or a Black institutional context. As related to sports, as early as 1963, Malcolm X had begun recruiting Cassius Clay into the group popularly known as the Black Muslims, or more formally, as the Nation of Islam. (Clay would later change his name to Muhammad Ali following his heavyweight boxing championship victory over Sonny Liston.) As much as any other development, Malcolm X's relationship with and influence upon Muhammad Ali consolidated and legitimized the merging heightened Black youth political militancy with Black athlete power potential. (Roberts \& Smith, 2016, cover image). When Muhammad Ali refused military induction in 1967 and, consequently, was stripped of his heavyweight championship title - an action ultimately overturned by the U.S. Supreme Court - the course and trajectory of Black athlete activism informed by broader community and societal issues were irreversibly joined. Muhammad Ali, in effect, became the "God Father" of Black athlete activism in the 1960s.

Jackie Robinson had been the face of Black athlete sociopolitical relevance from the post-WW II years through the 1950s. But it was in the wake of Ali establishing the activistathlete template that a generation of activist athletes and sports-focused protest efforts emerged: Arthur Ashe and his anti-apartheid efforts throughout the 1970s and 1980s; Bill Russell and Jim Brown and their open and vociferous support for the Civil Rights Movement over the course of their professional athletic careers; Tommie Smith, John Carlos, Kareem Abdul-Jabbar, Lucius Allen and Mike Warren and their protest actions around the 1968 Mexico City Olympic Games; Spencer Haywood and his anti-trust lawsuit against the National Basketball Association (NBA); Curt Flood and his fight against Major League Baseball for free agency; and the athlete-activist movements challenging racism and discrimination at predominantly White institutions that exploded from Syracuse University in the East, to the University of Wyoming, the University of California, Berkeley, Oregon State University, and of course San Jose State University in the West. The pattern of continuities and parallels between the substance and dynamics of Black circumstances and subsequent protest developments at SJSU in the fall of 1967 and at the University of Missouri in the fall of 2015 - forty-eight years later - are as revealing as they are striking. 
First of all, Black students at the University of Missouri have experienced circumstances and outcomes within their campus community that are commonplace among Black students today at many predominantly White collegiate institutions across the nation. From Clemson University, Yale, Northeastern University, and Princeton in the East, to the heartland universities of Kansas and Missouri, to the West coast institutions of Occidental, the University of California, Berkeley and San Jose State University, Black students have organized protest efforts since 2011 against what they generally define as institutionalized racism, alienation, exclusion, and repression of the scope and substance of their educational experiences on these campuses (Carson, 2015; Keppel, 2015). And, in fact, for the most part, Black students on these and other predominantly White campuses continue to be underrepresented in the general student populations and substantially over represented among athlete contingents in the revenueproducing sports of collegiate football and basketball. Similarly, in 2011 , only $6 \%$ of college presidents were Black. Only $6 \%$ of college faculty were Black as late as 2013 . Yet, $80 \%$ of faculties and $90 \%$ of institutional leaders overall were White at these universities.

The demands of Black student protests in the 21 st Century differ little from demands issued at SJSU in 1967: increases in Black student recruitment and financial support; increases in Black faculty and administrators; curriculum changes that reflect the history, politics, and current realities of the Black experience in America; programs that promise to change racially discriminatory and inhospitable campus sociocultural climates; etc. Some of the universities targeted by these Black student protests have likewise responded with regimens very much akin to those first promised and/or implemented at SJSU in 1967, including the appointing of diversity ombudsmen officers to monitor, report on, and resolve diversity-related issues on campus, and these other realities that have persisted since 1967. Predominantly White collegiate institutions continue to be as unprepared for Black student enrollment as they were in the 1960s and, therefore, are all but "institutionally blind and deaf" (Edwards, 2016). or simply in denial of the legitimacy of Black student concerns and interests. And it is these circumstances that provide the optimal environment for Black student/Black athlete activist collaboration. Developments at the University of Missouri in the fall of 2015 - as was the case at SJSU in the fall of 1967 virtually constitute a "textbook" case relative to the dynamics of this "political phase transition". (Davis, 2015).

As with the SJSU movement, it has taken 4-5 years to progress from initial expressions of athlete political activism to collegiate Black athlete demonstrations and threats of event boycotts over issues of racial inequities and injustice. And, most notably, reports of the incidents involved have not only been highly publicized in the mainstream traditional media, they were in most instances widely disseminated and commented upon in a medium not available in 1967 online social media. The trajectory of developments presaging the threatened University of Missouri athletes' football boycott can be dated from 2010 when the NBA Phoenix Suns wore jerseys emblazoned with "Los Suns" in protest of what the players believed to be draconian if not outright racist state of Arizona that initiated immigration policies. Over ensuing years, former University of California Los Angeles basketball player Ed O'Bannon, fought an anti-trust 
battle against the NCAA rule prohibiting its member institutions from compensating their athletes for use of their athletes names, images, and likenesses, while a group of former Northwestern University student-athletes endeavored to form a collegiate athletes' union (Farrey, 2015). In 2012, the Miami Heat NBA basketball team - led by the League's preeminent star, LeBron James - wore hoodies in silent protest in the wake of the killing of Black teenager Trayvon Martin (Heat don hoodies, 2012). Athletes from the NBA threatened not to play games against the Los Angeles Clippers after disclosure of tapes that revealed racist comments about African-Americans and Latinos, including Clippers players, made by Clippers' owner Donald Sterling (Curry, 2014). Los Angeles Lakers and other NBA players have joined protests over police violence against Blacks (LA Lakers' Kobe, 2014). Five National Football League St. Louis Rams football players gave a pre-game salute to slain Ferguson teen Mike Brown by taking the field giving the "hands up, don't shoot gesture" (No fines, 2014). During the National Anthem, Ariyana Smith, a player on the Knox College women's basketball team, walked out to the flag with her hands up in the "don't shoot" gesture, dropped to the floor before the flag, and lay there for "4 minutes and 30 seconds" in protest of the police killing the teenager Mike Brown and leaving his body lying in the street in Ferguson, Missouri for four and a half hours (Knox College, 2014). Football players at the University of Oklahoma spoke out against and protested racist chants by a campus fraternity after a Black player's profanity-laced statement of outrage over the fraternity's behavior and words went viral over the social media (Waldron, 2015). And unlike in 1967, even a historically Black institution had an incident of Black athlete rebellion when the football players at storied Grambling University undertook a week-long boycott of the school's football program over the physical condition of athletic facilities, forcing cancellation of a scheduled game against Jackson State (Associated Press, 2013). Athletes are also becoming more politically active and outspoken concerning non-racial issues. Athletes in a number of sports, many still active, revealed that they were gay (most notably, Michael Sam and Kwame Harris in football; John Amaechi, Will Sheridan, Brittney Griner, Jason Collins, and Derrick Gordon in basketball; and professional sports executives Billy Bean of the Oakland A's) (Openly gay athletes, n.d.), and Rick Welts of the NBA Golden State Warriors (NBA exec, n.d.). Meanwhile athletes such as Chris Kluwe, then a kicker with the Minnesota Vikings, came out forcefully in support of gay rights and gay marriage in 2012 (Kluwe, 2014).

The above expressions of activism by these sports figures established a climate and created templates for political activism, much as Muhammad Ali did in the 1960s. Similarly, also, contemporary political developments in the larger society have fueled and legitimized political activism for which the groundwork was already well underway within the sports arena.

Like the Black Power! movement of the 1960s, nothing has informed and framed Black athlete activism in the decade of the 21 st Century as much as the Black Lives Matter movement. Not surprisingly, in the age of social media, Black Lives Matter began as a hashtag that morphed into a movement. It is a movement that spread and grew within sport without a central leader or leadership organization, much like the revolt of the Black athlete in the 1960s. A lack of formal structure, and no binding agenda or specific set of clearly defined goals, and the political 
malleability and adaptability were functional assets of the Black Power! movement of the 1960s. Black Power! could portend and project almost any goal, from increased numbers of Black students on predominantly White campuses to establishing Black studies curriculum and all Black residential and cultural centers for them once they arrived on campus. Similarly, Black Lives Matter makes no specific demands, has no set agenda, no central leadership or leadership organization. Black Lives Matter applies on the campuses of the Universities of Missouri, Oklahoma, and Princeton no less than on the streets of Ferguson, Brooklyn, and Baltimore. But there are also downsides to this flexibility and adaptability. The Black Lives Matter movement can fuel, frame, inform and even inflame campus activism. But, with no definitive measures and markers of legitimate progress, as with Black Power!, it leaves its adherents open to co-optation and to confusing symbolism with substantive change, to pursuing goals that do not produce lasting change in institutional culture, and in the control and application of power. Demands for resignations of high officials within an institutional structure provide a case in point. Dr. Robert Clark resigned as president of SJSU. A new president was appointed by the same power structure and people who had hired and subsequently accepted the resignation of Dr. Clark. But the new president of SJSU in fact, and not surprisingly, knew less about the realities, dynamics, and mediation of racial issues on campus than Dr. Clark who had learned a great deal within that regard after working to surmount those challenges daily for over two years. Predictably, conditions slowly drifted back toward status quo conditions existing prior to the athlete boycottbased protest movement. Over time, as non-athlete student numbers rose, athletes were more "siloed" socially, academically, and politically by the athletic department and the University. Thus, any hope for lasting change in the institutional culture was buried in the systemic power shift.

In an article titled "Camouflaging Power and Privilege: A Critical Race Analysis of University Diversity Policies" (Iverson, 2007), the authors make a cogent argument for the downside of flexibility and adaptability of activism that lacks formal structure and leadership. In the very act of meeting expressed student demands, even with the best of intentions, educational institutions often succeed in nothing more than affirming and reinforcing the already entrenched images and perceptions of protesting minorities as the other, as largely outsiders who cannot compete or function "normally" without special programs, protections, and support systems. In the final analysis, universities such as SJSU, compelled to confront and pursue correction of antiBlack exclusion, discrimination, and other race-related issues under threat of protests and Black athlete boycotts, ironically end up compounding the very problems that they seek to resolve. As successive cohorts of students enroll and graduate and as the original issues precipitating corrective actions, the protest movements taken to secure them fade from common knowledge and awareness. Furthermore, the hard won programs and support systems targeting Black student issues and interests become increasingly to be perceived within the larger campus culture as either no longer warranted or as special treatment for a group apart, a group as either unduly privileged or one that otherwise would not be able to compete. Again, as was the case at SJSU, institutional supports for such corrective measures in either case begin to erode. Over the course 
of successive administrations, most such supports no longer function as viable substantive programs, or worse, are discontinued altogether. Typically, decisions leading to a gradual retrenchment and re-institution of the status quo are the prerogatives of university power structures to which the Black student protestors and their supporters have little or no access or input. At SJSU in 2012, Black students were again engaged in a campus protest movement with sweeping goals and demands almost identical to the those put forth in the fall of 1967 (Early \& Murphy, 2014). The one major difference has been that students today have access to social media, the greatest tool of protest organization in history - a history that is again being repeated. Only time will tell if the protest movements at SJSU, the University of Missouri and or other campuses today will approach the challenges that they face with more wisdom, vision, and efficacy - and whether, in the end, they will have longitudinal effects with (or without) leveraging the power potential of Black athletes.

And finally, it must be emphasized that nothing stated here should be construed to be a condemnation or discouragement of anti-racism protest efforts by Black collegiate students and athletes. Racism is the evil that was at the core of slavery, "America's original sin", segregation, lynching and other forms of barbaric inhumanity (Ganz, 2015). Today it remains this nation's most divisive and volatile institutional, political and sociocultural burden, and it must be vigorously confronted and vociferously addressed in every realm of American life. Silence has always been evil's greatest and most consistently dependable ally. The all but impossible odds against any single movement effort achieving total and lasting success is no reason or justification to forego this battle. As much as any other lesson to be drawn from the experiences and legacies of Black campus protest movements there is this: the challenges to achieving the promise of America, of bringing into existence that more perfect union are diverse and dynamic; therefore, our struggles to those ends must be multi-faceted and perpetual - and there are no final victories! The abolition of slavery, despite having been accomplished at the price of a civil war, was not a "final victory"; Brown v. Board. of Education, Topeka, Kansas and similarly successful efforts to dismantle separate but equal laws, did not constitute "final victories"; the Civil Rights Act of 1964 and the Voting Rights Act of 1965 clearly were not "final victories"; not even Roe v. Wade legalizing women's rights to abortion, birth control, and other health services (which had a particularly significant impact upon the lives and outcomes of so many low income women and women of color) was not a "final victory". The current generation of progressive activists and political interests are still engaged in battles to secure and sustain indelible gains in all of these areas. Only this time around, the battlefield takes place on the social media plane.

Irrespective, then, of prospects for real, substantive, and enduring progressive gains in the struggle against racism in all of its diverse forms, it still must be opposed and resisted. Protests, boycotts, and marches against racism and exclusion must continue - even when protestors and boycotters appear to be marching up the down escalator of change. And, if these struggles most legitimately do not take place on our campuses, and particularly within the racism-afflicted cultures and structures of our institutions of higher education - then where? 


\section{References}

Associated Press. (2013, October). Jackson St. to pursue legal action. Retrieved July 26, 2016, from http://espn.go.com/college-football/story/_id/9864598/jackson-state-pursuelitigation-grambling-state-following-forfeit

Carson, A. D. (2015, November). Does Missouri president ouster offer lessons to universities grappling with a racist past? Retreived July 26, 2016, from https://theconversation.com/does-missouri-president-ouster-offer-lessons-to-universitiesgrappling-with-a-racist-past-50493

Curry, C. (2014, April). NBA players were willing to boycott if Sterling wasn't punished. Retrieved July 26, 2016, from http://abcnews.go.com/US/nba-players-boycott-sterlingpunished/story?id=23520534

Davis, L. P. (2015, November). Why have the demands of black students changed so little since the 1960s? Retrieved July 26, 2016, from https://theconversation.com/why-have-thedemands-of-black-students-changed-so-little-since-the-1960s-50695

Early, D. E., \& Murphy, K. (2014, March). San Jose State's festering racial issues challenge black students. Retrieved July 26, 2016, from http://www.mercurynews.com/education/ci_25256488/san-jose-states-festering-racialissues-challenge-black

Edwards, H. (1969). The revolt of the black athlete (Vol. 69). New York, NY: Free Press.

Edwards, H. (2016). The fourth wave: Black athlete protests in the second decade of the $21^{\text {st }}$ century. Invited key note at NASSS Annual Meeting in Tampa, FL.

Farrey, T. (2015, August). Northwestern players denied request to form first union for athletes. Retrieved July 26, 2016, from http://espn.go.com/collegefootball/story/_id/13455477/nlrb-says-northwestern-players-cannot-unionize

Ganz, M. (2015, November). Here's how history is shaping the \#studentblackout movement. Retrieved July 26, 2016, from https://theconversation.com/heres-how-history-is-shapingthe-studentblackout-movement-51078

Haley, A. (1992). The autobiography of Malcolm X. New York, NY: Ballantine Books

Heat don hoodies after teen's death.(2012, March). Retrieved July 26, 2016, from http://espn.go.com/nba/truehoop/miamiheat/story/_id/7728618/miami-heat-don-hoodiesresponse-death-teen-trayvon-martin

Iverson, S. V. (2007). Camouflaging power and privilege: A critical race analysis of university diversity policies. Educational Administration Quarterly, 43(5), 586-611.

Keppel, B. (2015, March). View from Oklahoma: Race exists, although some may not see it. Retrieved June 26, 2016, from https://theconversation.com/view-from-oklahoma-raceexists-although-some-may-not-see-it-38821

Kluwe, C. (2014, January). I Was An NFL player until I was fired by two cowards and a bigot. Retrieved July 26, 2016, from http://deadspin.com/i-was-an-nfl-player-until-i-was-firedby-two-cowards-an-1493208214Knox College (2014, December). Knox College suspends player after Mike Brown demonstration during basketball game. Retrieved July 26, 2016, from http://www.buzzfeed.com/jazminmb/illinois-college-suspends-playerafter-mike-brown-t0fd\#.ybDLQAVWX1

LA Lakers' Kobe. (2014, December). LA Lakers' Kobe Bryant and other NBA players join California protests over police violence. Retrieved July 26, 2016, from http://www.christiantoday.com/article/la.lakers.kobe.bryant.and.other.nba.players.join.cal ifornia.protests.over.police.violence/44223.htm 
NBA exec. (n.d.). NBA exec Rick Welts announces he's gay - video -. Retrieved July 26, 2016, from http://content.time.com/time/video/player/0,32068,947476098001_2072000,00.html

No fines. (2014, December). No fines for Rams players' salute. Retrieved July $\overline{26}$, 2016, from http://espn.go.com/nfl/story/_id/11963218/the-five-st-louis-rams-players-saluted-slainteenager-michael-brown-sunday-game-not-fined

Openly gay athletes. (n.d.). Openly gay athletes. Retrieved July 26, 2016, from http://www.sportingnews.com/photos/4495927-gay-athletes-sports-list-players-nfl-mlbnba-lesbian/slide/223950

Roberts, R., \& Smith, J. M. (2016). Blood brothers: The fatal friendship between Muhammed Ali and Malcom X. New York, NY: Basic Books.

Student unrest at San Jose State College 1967-68. (1967). Unpublished manuscript.

Waldron, T. (2015, March). Oklahoma football players speak out against racist fraternity. Retrieved July 26, 2016, from

http://thinkprogress.org/sports/2015/03/10/3631809/oklahoma-football-players-joincampus-protest-racist-fraternity-video/ 